\title{
Substrate utilization in man: effects of dietary fat and carbohydrate
}

Citation for published version (APA):

van Verboeket, W. P. H. G., Westerterp, K. R., \& ten Hoor, F. (1994). Substrate utilization in man: effects of dietary fat and carbohydrate. Metabolism-Clinical and Experimental, 43(2), 152-156.

https://doi.org/10.1016/0026-0495(94)90237-2

Document status and date:

Published: 01/01/1994

DOI:

10.1016/0026-0495(94)90237-2

Document Version:

Publisher's PDF, also known as Version of record

Document license:

Taverne

Please check the document version of this publication:

- A submitted manuscript is the version of the article upon submission and before peer-review. There can be important differences between the submitted version and the official published version of record.

People interested in the research are advised to contact the author for the final version of the publication, or visit the DOI to the publisher's website.

- The final author version and the galley proof are versions of the publication after peer review.

- The final published version features the final layout of the paper including the volume, issue and page numbers.

Link to publication

\footnotetext{
General rights rights.

- You may freely distribute the URL identifying the publication in the public portal. please follow below link for the End User Agreement:

www.umlib.nl/taverne-license

Take down policy

If you believe that this document breaches copyright please contact us at:

repository@maastrichtuniversity.nl

providing details and we will investigate your claim.
}

Copyright and moral rights for the publications made accessible in the public portal are retained by the authors and/or other copyright owners and it is a condition of accessing publications that users recognise and abide by the legal requirements associated with these

- Users may download and print one copy of any publication from the public portal for the purpose of private study or research.

- You may not further distribute the material or use it for any profit-making activity or commercial gain

If the publication is distributed under the terms of Article $25 \mathrm{fa}$ of the Dutch Copyright Act, indicated by the "Taverne" license above, 


\title{
Substrate Utilization in Man: Effects of Dietary Fat and Carbohydrate
}

\author{
Wilhelmine P.H.G. Verboeket-van de Venne, Klaas R. Westerterp, and Foppe ten Hoor
}

\begin{abstract}
In man there is evidence that the ability to adjust fat oxidation to fat intake is less effective than the ability to adjust carbohydrate and protein oxidation to carbohydrate and protein intake. The short-term (3-day) effects of a low-fat (LF), mixed (M), and high-fat (HF) diet on human substrate balances were studied using a respiration chamber. Subjects were 14 young female students classified by means of their scores on psychometric questionnaires as "restrained" or "unrestrained" eaters. Subjects were in energy balance, ie, the mean difference between energy intake (EI) and energy expenditure (EE) was $86 \pm 85$ $\mathrm{kJ} / \mathrm{d}$. The fat content of the food significantly influenced the 24-hour respiratory quotient (RQ) and nonprotein respiratory quotient (NPRO). For both the LF and M diets, the 24-hour RQ was significantly lower than the food quotient (FQ), whereas the $\mathrm{RQ}$ on the HF diet was not different from the FQ. Oxidation of fat and carbohydrate significantly increased with, respectively, an increasing fat and carbohydrate content of the diet for both restrained- and unrestrained-eating subjects. Restrained-eating subjects showed a decreased fat oxidation compared with unrestrained eaters in response to a HF diet, resulting in a positive fat balance for restrained-eating subjects. On a LF diet, fat balance was negative for both groups of subjects, indicating net endogenous fat oxidation. In conclusion, restrained-eating subjects have more difficulty in the handling of a HF diet, possibly explaining their higher susceptibility to becoming obese.
\end{abstract}

Copyright 1994 by W.B. Saunders Company

$\mathbf{M}$ AINTAINING A STABLE body weight requires that over time, energy intake (EI) cquals energy expenditure (EE) and also that intakes of protein, fat, and carbohydratc cqual the oxidation of cach substrate. ' In conditions of energy or substrate imbalance, changes occur in the body stores and hence body weight and body composition. A high-fat (HF) intake is often associated with an increasing prevalence of obesity. ${ }^{3-5}$ There are several mechanisms for this association. First, a HF diet leads to an increase of El, ${ }^{5-7}$ or a decrease of EE. ${ }^{8.9}$ Second, the body fails to adjust fat oxidation in response to excess fat intake. ${ }^{1.2}$

Another aspect that must be considered in the processes leading to obesity is a metabolic difference between individuals in the handling of dietary fat. Studies in post-obese subjects have suggested that decreased fat oxidation may be related to subsequent body weight gain." ${ }^{911}$ Thomas et al ${ }^{11}$ reported that lean subjects have a greater ability to increase fat oxidation in response to a HF diet than do obcse subjects. This could result in a smaller increase of body fat in lean as compared with obese subjects when both consume a HF diet.

A primary purpose of the present study was to investigatc the effect of an isoenergetic exchange of fat and carbohydrate on substrate metabolism, ie, oxidation and overall balance of protein, fat, and carbohydrate. A second aim was to determine metabolic responses to dietary fal and carbohydrate of subjects being more or less susceptible to becoming obese. By means of scores on psychometric questionnaires, a distinction was made in the relevant subject characteristics between a "restrained" or "unrestrained" attitude towards eating.

From the Department of Human Biology, University of Limburg. Maastricht, The Netherlands.

Submitted August 10, 1992; accepted April 19, 1993.

Address reprint requests to Wilhelmine P.H.G. Verboeket-van de Venne, PhD, Department of Human Biology, University of Limburg PO Box 616, 6200 MD Maastricht. The Netherlands.

Copyright 1994 by W.B. Saunders Company

0026-0495/94/4302-0005\$03.00/0

\section{SUBJECTS AND METHODS}

Subjects

Fourteen healthy young female subjects participated in the study. Their physical characteristics are presented in Table 1. There were no significant differences between the restrained- and un estrained-eating subjects with respect to age. lieight, weight, or percentage body fat. The procedures used in the study were carefully explained to each subject hefore she gave her consent to participate. The protocol was reviewed and approved by the University of Limburg Ethical Committee.

\section{Attitude Towards Eating}

Characterization of restrained-and unrestrained-eating subjects was accomplished by means of scores on psychometric questionnaires. The following two types of psychometric questionnaires were used: the Herman-Polivy (H-P) restraint scale. ${ }^{2}$ which is designed to identify dieters and is mainly weight-concerned. ${ }^{13}$ and the Three-Factor Eating Questionnaire (TFEQ) of Stunkard and Messick. ${ }^{4}$ which is designed to measure successful dieting and is mainly food-concerned. ${ }^{13}$ The TFEQ was used to discriminate between "cognitive restraint" and "unrestraint" concerning the scores on the cognitive restraint factor $F_{1}$. In the subject population We use at the Department of Human Biology of the University af Limburg in Maastricht, the median of the H-P scores was 15 and of the $F_{1}$ scores 9. ${ }^{13}, 15$, 10 Subjects were classified as restrained eaters when the H-P score exceeded 15 or $F_{1}$ score exceeded 9 ; unrestrained-eating subjects had an H-P score no greater than 1.5 and an $F_{1}$ score no greater than 9 . From the seven subjects in the present study classified as restrained eaters, one subject was restrained by being food-concerned, four subjects by being weightconcerned, and two subjects by being food-and weight-concerned.

\section{Experimental Design}

Subjects were fed to an estimated energy balance by consuming it low-fat (LF) and a HF diet over 3-day intervals. The order of administration of LF and HF diets was randomized. Twelve subjects additionally consumed a mixed (M) diet. The interval between two experimental periods was at least 1 ditys. During the first 2 days on each dietary regimen, food was provided and consumed at home, and the last day of each period was spent in a respiration chamber. In this chamber, oxygen consumption and carbon dioxide production, and hence the respiratory quotient (RO), were the main measurements (see helow). Urine samples were collected to determine nitrogen excretion and hence calculate 
Table 1. Physical Characteristics of the Subjects and Order of Treatment

\begin{tabular}{lccccc} 
Subject No. & $\begin{array}{c}\text { Age } \\
(\mathrm{yr})\end{array}$ & $\begin{array}{c}\text { Height } \\
(\mathrm{m})\end{array}$ & $\begin{array}{c}\text { Weight } \\
\langle\mathrm{kg})\end{array}$ & $\begin{array}{c}\text { Percentage } \\
\text { Body Fat }\end{array}$ & $\begin{array}{c}\text { Order of } \\
\text { Treatment }\end{array}$ \\
\hline Restrained & & & & & \\
1 & 20 & 1.75 & 65.5 & 19.8 & LF-HF-M \\
2 & 20 & 1.73 & 71.1 & 21.1 & LF-HF-M \\
3 & 21 & 1.71 & 64.5 & 26.5 & LF-HF-M \\
4 & 21 & 1.60 & 59.5 & 22.7 & HF-LF-M \\
5 & 21 & 1.73 & 67.2 & 28.6 & HF-LF-M \\
6 & 21 & 1.75 & 67.7 & 21.7 & LF-HF-M \\
7 & 19 & 1.61 & 71.3 & 29.6 & LF-HF \\
Mean & 20.4 & 1.70 & 66.7 & 24.3 & \\
SD & 0.8 & 0.06 & 4.1 & 3.9 & \\
Unrestrained & & & & & \\
8 & 20 & 1.71 & 80.1 & 32.0 & LF-HF-M \\
9 & 22 & 1.71 & 68.4 & 28.6 & HF-LF-M \\
10 & 19 & 1.71 & 69.7 & 28.9 & HF-LF-M \\
11 & 19 & 1.70 & 57.7 & 22.2 & LF-HF-M \\
12 & 24 & 1.76 & 62.6 & 21.0 & LF-HF-M \\
13 & 20 & 1.63 & 61.9 & 28.4 & HF-LF-M \\
14 & 20 & 1.69 & 65.7 & 28.0 & HF-LF \\
Mean & 20.6 & 1.70 & 66.6 & 27.0 & \\
SD & 1.8 & 0.04 & 7.2 & 3.9 & \\
\hline & & & & &
\end{tabular}

EE and substrate oxidation. EI for the maintenance of energy balance was based on the calculated basal metabolic rate (BMR) ${ }^{17}$ of the subjects multiplied by 1.76 on days 1 and 2 (Verboeket-van de Venne and Westerterp, unpublished observations); EI on day 3 while in the respiration chamber equaled $1.29 \times$ BMR. $^{1 \times}$

\section{Diets}

The diets were taken as four meals daily, a breakfast at 8:00 AM (20\% of daily EI), a lunch at 1:00 PM (25\% of EI), a dinner at 6:00 PM (45\% of EI), and an evening snack at $8: 30$ PM (10\% of EI). Total EI was the same for the three diets. The LF diet contained $15 \%$ of EI as protein, $10 \%$ as fat, and $75 \%$ as carbohydrate; the $\mathrm{M}$ diet contained $15 \%$ of EI as protein, $30 \%$ as fat, and $55 \%$ as carbohydrate; and the HF diet contained $15 \%$ of EI as protein. $50 \%$ as fat, and $35 \%$ as carbohydrate. Macronutrient composition of the diets was calculated using the Dutch food composition table. ${ }^{19}$ The food quotient (FQ), defined as the ratio of $\mathrm{CO}_{2}$ produced to $\mathrm{O}_{2}$ consumed during the oxidation of a representative sample of the diet, ${ }^{20}$ was calculated using the following equation ${ }^{21}$ : $\mathrm{O}_{2}$ consumption $(\mathrm{L} / \mathrm{d})=(0.966 \cdot$ protein intake $)+(2.019 \cdot$ fat intake $)+$ $\left(0.829\right.$ - carbohydrate intake), and $\mathrm{CO}_{2}$ production $(\mathrm{L} / \mathrm{d})=$ $(0.774 \cdot$ protein intake $)+(1.427 \cdot$ fat intake $)+(0.829 \cdot$ carbohydrate intake), where the intake of protein, fat, and carbohydrate is expressed in grams per day.

\section{Procedures}

Subjects weighed themselves (without clothing) on the morning of days 1, 3, and 4 upon rising, after voiding, and before any food or drink consumption using a digital balance (Seca delta, model 707; Vogel \& Halke, Hamburg, Germany) accurate to $0.1 \mathrm{~kg}$.

Body composition was assessed once in the morning immediately after the subjects left the respiration chamber, using hydrostatic weighing with direct assessment of lung volume (Volugraph 2000 . Bunnik, The Netherlands). The percentage of body fat was calculated using the equation of Siri. ${ }^{22}$

A twenty-four-hour urine sample was collected on day 3 of each dietary period, while subjects were staying in the respiration chamber. Samples were collected in containers with $8 \mathrm{~mL} \mathrm{H}_{2} \mathrm{SO}_{4}$ to prevent nitrogen loss through evaporation; volume and nitrogen concentration were measured subsequently, the latter using a Heraeus analyzer (type CHN-O-Rapid)

Oxygen consumption and carbon dioxide production were measured in a respiration chamber. The chamber was $14 \mathrm{~m}^{3}$ and furnished with a bed, chair, table, television, radio, telephone, wash bowl, and toilet facilities. and was ventilated with fresh air at a rate of $50 \mathrm{~L} / \mathrm{min}$. The ventilation rate was measured with a dry gas meter (Schlumberger, type G6, Meterfabriek Schlumberger, Dordrecht. The Netherlands). The concentration of oxygen and carbon dioxide was measured using a paramagnetic $\mathrm{O}_{2}$ analyzer (Servomex, type OA 184: Servomex, Crowborough, Sussex, UK) and an infrared $\mathrm{CO}_{2}$ analyzer (Hartmann \& Braun Aktiensgesellschaft, Frankfurt, Germany, type URAS 3G). Ingoing air was analyzed once every 15 minutes, and outgoing air once every 5 minutes. The gas sample to be measured was selected by a computer that also stored and processed the data. The RQ was calculated as the ratio of $\mathrm{CO}_{2}$ produced to $\mathrm{O}_{2}$ consumed; EE was calculated from $\mathrm{O}_{2}$ consumption, $\mathrm{CO}_{2}$ production, and urinary nitrogen excretion according to the method of Weir. ${ }^{2+}$ The physical activity of the subjects was monitored by means of a radar system based on the Doppler principle. During the daytime, subjects were allowed to move freely, sit. lie down, study, use the telephone. listen to the radio, and watch television; only sleeping and strenuous exercise were not allowed.

\section{Analysis of Data}

The 24-hour RQ and 24-hour EE were calculated from 7:30 AM to 7:30 AM. Urinary nitrogen excretion was determined for the same interval to allow calculation of the nonprotein respiratory quotient (NPRQ). Protein, fat, and carbohydrate oxidations were calculated according to the method of Jéquier et al. ${ }^{21}$ The effects of diet composition on the RQ, NPRQ, substrate oxidation, and substrate balance (intake minus oxidation) were analyzed by repeated-measures ANOVA and Scheffé F tests or paired $t$ tests. Changes between groups of restrained- and unrestrained-eating subjects on the same diet were tested using ANOVA, with "attitude towards eating" as the grouping factor. Analysis of covariance (ANCOVA) was used to detect differences between restrained- and unrestrained-eating subjects concerning the relationship between fat balance and fat intake. In the text, tables, and figures, data are presented as the mean \pm standard error of the mean.

\section{RESULTS}

Body mass showed a slight increase $(0.2 \pm 0.1 \mathrm{~kg})$ over the 2 days in free-living conditions on all three diets. During the subsequent day in the respiration chamber, body weight decreased $(0.5 \pm 0.1 \mathrm{~kg})$. There were no significant differences in changes of body mass due to the composition of the diet. Over the 3-day intervals, body mass changes were not significantly different from zero.

No statistically significant differences in 24-hour EE between restrained- and unrestrained-eating subjects were observed on the LF, M, and HF diet (Table 2). Garrow ${ }^{25}$ stated that an adult is in energy balance when the difference between $\mathrm{EI}$ and $\mathrm{EE}$ is less than $600 \mathrm{~kJ} / \mathrm{d}$. Energy balance was determined by subtracting EE from EI. EI - EE was near zero on all three diets, averaging $+86 \pm 85 \mathrm{~kJ} / \mathrm{d}$ (range, $-1,583$ to $+894 \mathrm{~kJ} / \mathrm{d}$ ).

There was a highly significant effect of diet composition on the RQ $(P<.001)$. On a LF or M diet, the RQ was 
Table 2. Average Daily (24-hour) EE, RO, NPRO, and FO for Restrained- $(n=7)$ and Unrestrained-Eating $(n=7)$ Subjects on the Three Diets

\begin{tabular}{|c|c|c|c|c|c|c|}
\hline & \multicolumn{2}{|c|}{ LF } & \multicolumn{2}{|c|}{$\mathrm{M}^{*}$} & \multicolumn{2}{|c|}{$\mathrm{HF}$} \\
\hline & Mean & SE & Mean & SE & Mean & $\mathrm{SE}$ \\
\hline \multicolumn{7}{|c|}{ Restrained-eating subjects } \\
\hline 24-hour EE (kJ/d) & 8,525 & 182 & 8,179 & 216 & 8,209 & 214 \\
\hline 24-hour RO & 0.908 & 0.003 & 0.860 & 0.008 & $0.829 \top$ & 0.004 \\
\hline 24-hour NPRQ & 0.929 & 0.003 & 0.872 & 0.010 & $0.835 \ddagger$ & 0.005 \\
\hline FO & 0.936 & 0.000 & 0.879 & 0.000 & 0.820 & 0.000 \\
\hline \multicolumn{7}{|c|}{ Unrestrained-eating subjects } \\
\hline 24-hour EE (kJ/d) & 8,698 & 276 & 8,649 & 135 & 8,604 & 146 \\
\hline 24-hour RO & 0.898 & 0.009 & 0.857 & 0.005 & $0.816 t$ & 0.004 \\
\hline 24-hour NPRO & 0.913 & 0.011 & 0.868 & 0.006 & $0.818 \mp$ & 0.004 \\
\hline $\mathrm{FQ}$ & 0.936 & 0.000 & 0.878 & 0.000 & 0.820 & 0.000 \\
\hline
\end{tabular}

${ }^{*} \mathrm{n}=6$.

thestrained $v$ unrestrained eaters, $P<.05$

†Restrained $v$ unrestrained eaters, $P<.05$

significantly lower than the FQ $(P<.001)$, whereas the RQ was not different from the $\mathrm{FQ}$ on a $\mathrm{HF}$ diet (Fig 1). Respiratory data for restrained- and unrestrained-cating subjects are presented in Table 2 . The RQ and NPRQ were significantly lower for unrestrained-eating subjects on the HF diet. No statistically significant differences in the RQ and NPRQ between restrained- and unrestrained-eating subjects were observed on the LF or M diet.

The mean intake, oxidation, and balance (ic, intake - oxidation) of protein, carbohydrate, and fat on the LF, M, and HF diet are presented in Fig 2. There was no significant effect of diet composition on protein oxidation. Protein balance was near zero for both the HF diet $(-0.8 \pm 1.9 \mathrm{~g} / \mathrm{d}, \mathrm{NS})$ and the $\mathrm{M} \operatorname{diet}(-0.5 \pm 2.1 \mathrm{~g} / \mathrm{d}, \mathrm{NS})$, and was significantly positive on the LF diet $(+7.2 \pm 2.7$ $\mathrm{g} / \mathrm{d}, P<.05)$. Oxidation of carbohydrate increased significantly with increasing dietary carbohydrate content $(P<.001)$. Carbohydrate balance was positive on the LF diet $(+44.3 \pm 9.0 \mathrm{~g} / \mathrm{d}, P<.001)$ and the $\mathrm{M} \operatorname{dict}$ $(+35.7 \pm 6.1 \mathrm{~g} / \mathrm{d}, P<.001)$, but not on the HF diet $(+0.2 \pm 4.2 \mathrm{~g} / \mathrm{d}, \mathrm{NS})$. Fat oxidation increased significantly with increasing dietary fat $(P<.001)$, presumably because the concomitant decrease in dietary carbohydrate intake led to lower insulin levels, thereby permitting more fat to be

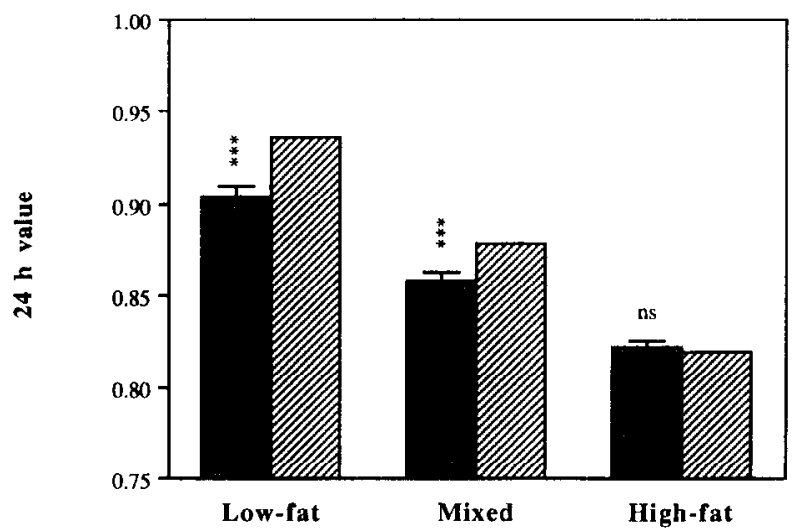

Fig 1. Mean RQ (E) and FQ (D) over 24 hours under different feeding conditions $(\mathrm{n}=12)$. ${ }^{* *} P<.001$; $n s$, no significance.
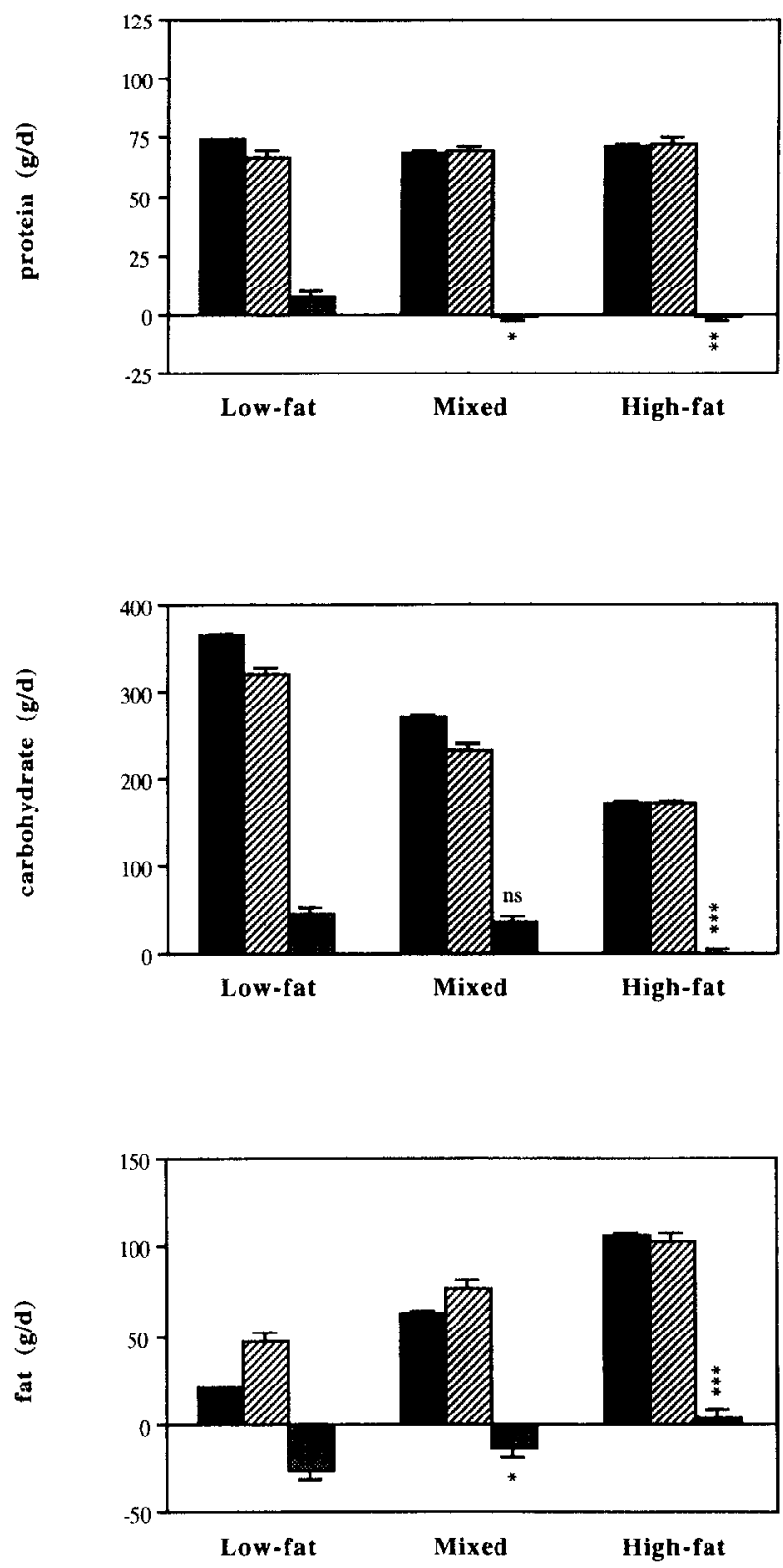

Fig 2. Mean intake ( $\square$ ), oxidation ( $\mathrm{J})$, and balance ( $\square$ ) of protein, carbohydrate, and fat over 24 hours under different feeding conditions ( $n=12$ ). Statistical significance comparing substrate balance on the $M$ and HF diets with the LF diet: ${ }^{* * * P}<.001 ;{ }^{* * P}<.01 ; * P<.05$; ns, no significance.

oxidized. The difference between fat intake and fat oxidation was smallest on the HF diet $(+3.9 \pm 4.4 \mathrm{~g} / \mathrm{d}$. NS $)$ compared with the $\mathrm{M}$ diet $(-14.0 \pm 4.6 \mathrm{~g} / \mathrm{d}, P<.05)$ and the LF diet $(-26.2 \pm 4.5 \mathrm{~g} / \mathrm{d}, P<.001)$.

Protein oxidation was significantly lower for unrestrainedeating subjects on the LF diet, resulting in a more positive protein balance compared with restrained-eating subjects (Table 3). There were no significant differences between restrained- and unrestrained-cating subjects with respect to oxidation and overall balance of carbohydrate on the LF, $\mathrm{M}$, or HF diet (Table 4). Unrestrained-eating subjects had a significantly increased rate of fat oxidation while on the HF diet (Table 5). The fat balance on the HF diet was 
Table 3. Protein Intake, Oxidation, and Balance (intake - oxidation) for Restrained- $(n=7)$ and Unrestrained-Eating ( $n=7$ ) Subjects on the Three Diets

\begin{tabular}{|c|c|c|c|c|c|c|}
\hline & \multicolumn{2}{|c|}{ LF } & \multicolumn{2}{|c|}{$M^{*}$} & \multicolumn{2}{|c|}{$\mathrm{HF}$} \\
\hline & Mean & SE & Mean & SE & Mean & $\mathrm{SE}$ \\
\hline \multicolumn{7}{|c|}{ Restrained-eating subjects } \\
\hline Protein intake & 73.2 & 0.0 & 67.9 & 0.0 & 70.9 & 0.0 \\
\hline Protein oxidation & $71.1 \dagger$ & 1.7 & 70.8 & 1.6 & 74.2 & 1.6 \\
\hline Protein balance & $2.1 \mp$ & 1.7 & -2.9 & 1.6 & -3.3 & 1.6 \\
\hline \multicolumn{7}{|c|}{ Unrestrained-eating subjects } \\
\hline Protein intake & 74.3 & 1.1 & 69.4 & 1.5 & 71.8 & 0.9 \\
\hline Protein oxidation & $61.7 \dagger$ & 3.9 & 67.6 & 4.0 & 69.6 & 4.2 \\
\hline Protein balance & $12.6 \ddagger$ & 3.5 & 1.8 & 3.9 & 2.2 & 3.6 \\
\hline
\end{tabular}

NOTE. Data are expressed as grams per day.

${ }^{*} \mathrm{n}=6$.

†Restrained $v$ unrestrained eaters, $P<.05$.

$\neq$ Restrained $v$ unrestrained eaters, $P<.05$.

significantly more positive for the restrained-eating subjects than for the unrestrained-eating subjects $(P=.052)$. By plotting fat balance as a function of fat intake, we showed that the lines obtained for restrained-eating subjects (fat balance $=0.38 \cdot$ fat intake $-30.5 ; d f=17, r=.71, P<.01$ ) and unrestrained-eating subjects (fat balance $=0.34 \cdot \mathrm{fat}$ intake $-39.1 ; d f=17, r=.64, P<.01)$ are different with respect to the intercept (ANCOVA, $F$ value $=5.46$, $P<.05)$. This means that there is a statistically significant trend for increased fat retention in the restrained-eating subjects.

The effect of dietary fat and carbohydrate on substrate balance for restrained- and unrestrained-eating subjects is summarized in Table 6. For unrestrained-eating subjects, protein balance was significantly more positive on the LF diet (compared with the HF diet), whereas diet composition had no effect on protein balance in restrained-eating subjects. Carbohydrate balance was significantly (morc) positive and fat balance (more) negative on the LF diet both for restrained-and unrestrained-eating subjects.

\section{DISCUSSION}

In the present study, we investigated the relationship between substrate intake and substrate oxidation under different feeding conditions by comparing the 24-hour RQ, reflecting the fuel mixture oxidized, with the mean FQ,

Table 4. Carbohydrate Intake, Oxidation, and Balance (intake oxidation) for Restrained- $(n=7)$ and Unrestrained-Eating $(n=7)$ Subjects on the Three Diets

\begin{tabular}{|c|c|c|c|c|c|c|}
\hline & \multicolumn{2}{|c|}{ LF } & \multicolumn{2}{|c|}{$M^{*}$} & \multicolumn{2}{|c|}{$\mathrm{HF}$} \\
\hline & Mean & SE & Mean & $\mathrm{SE}$ & Mean & SE \\
\hline \multicolumn{7}{|l|}{ Restrained-eating subjects } \\
\hline Carbohydrate intake & 360.7 & 0.0 & 266.0 & 0.0 & 170.6 & 0.0 \\
\hline Carbohydrate oxidation & 318.7 & 6.9 & 227.4 & 11.3 & 176.7 & 3.1 \\
\hline Carbohydrate balance & 42.0 & 6.9 & 38.6 & 11.3 & -6.1 & 3.1 \\
\hline \multicolumn{7}{|l|}{ Unrestrained-eating subjects } \\
\hline Carbohydrate intake & 366.4 & 5.7 & 271.7 & 5.7 & 174.1 & 3.5 \\
\hline Carbohydrate oxidation & 310.1 & 15.1 & 238.8 & 4.9 & 166.3 & 6.0 \\
\hline Carbohydrate balance & 56.3 & 16.5 & 32.9 & 5.6 & 7.8 & 6.2 \\
\hline
\end{tabular}

NOTE. Data are expressed as grams per day.

${ }^{*} n=6$.
Table 5. Fat Intake, Oxidation, and Balance (intake - oxidation) for Restrained- ( $n=7)$ and Unrestrained-Eating $(n=7)$ Subjects on the Three Diets

\begin{tabular}{|c|c|c|c|c|c|c|}
\hline & \multicolumn{2}{|c|}{ LF } & \multicolumn{2}{|c|}{$M^{*}$} & \multicolumn{2}{|l|}{ HF } \\
\hline & Mean & SE & Mean & $\mathrm{SE}$ & Mean & SE \\
\hline \multicolumn{7}{|c|}{ Restrained-eating subjects } \\
\hline Fat intake & 20.8 & 0.0 & 62.6 & 0.0 & 106.0 & 0.0 \\
\hline Fat oxidation & 41.7 & 2.8 & 73.2 & 6.8 & $94.7 \dagger$ & 5.5 \\
\hline Fat balance & -20.9 & 2.8 & -10.6 & 6.8 & $11.3 \ddagger$ & 5.5 \\
\hline \multicolumn{7}{|c|}{ Unrestrained-eating subjects } \\
\hline Fat intake & 21.2 & 0.4 & 64.1 & 1.5 & 108.0 & 2.0 \\
\hline Fat oxidation & 54.1 & 7.1 & 81.4 & 5.9 & $111.2 t$ & 3.1 \\
\hline Fat balance & -32.9 & 7.0 & -17.3 & 6.5 & $-3.2 \ddagger$ & 3.9 \\
\hline
\end{tabular}

NOTE. Data are expressed as grams per day.

${ }^{*} n=6$.

tRestrained $v$ unrestrained eaters, $P<.05$.

¥Restrained $v$ unrestrained eaters, $P=.052$.

based on the nutrient composition of the diet. In conditions of prolonged deviations from the energy balance, a subject stores or mobilizes nearly all energy in the form of body fat. Over intervals longer than 24 hours, a $R Q$ greater than the FQ indicates that fat oxidation is less than fat intake, and a RQ less than the FQ indicates mobilization of energy from body fat stores. In the present study, we observed a highly significant effect of diet composition on the RQ, with the lowest value on the HF diet and the highest on the LF diet (Fig 1). The difference between the RQ and FQ was smallest on the $\mathrm{HF}$ diet $(\mathrm{RQ}-\mathrm{FQ}=+0.003 \pm 0.003 v$ $-0.031 \pm 0.005$ on the LF $\operatorname{diet} ; P<.001)$, reflecting a cluser correspondence of substrale oxidation with substrate intake. Other studies investigating the relationship between dietary fat and carbohydrate and substrate utilization also report a greater difference between the $R Q$ and $F Q$ when a LF (high-carbohydrate) diet is consumed. ${ }^{89,26.27}$ There are two possible reasons for this finding. First, the experimental HF diet appears to be the one most closely resembling the subjects' habitual diet. Note that a dietary fat content of $40 \%$ of the total EI is more or less "normal" in Western

Table 6. Substrate Balances (intake - oxidation) and Energy Balance (EI - EE) for Restrained- ( $=7$ ) and Unrestrained-Eating ( $\mathbf{n}=7$ ) Subjects on the LF and HF Diet

\begin{tabular}{|c|c|c|c|c|}
\hline & \multicolumn{2}{|c|}{ LF } & \multicolumn{2}{|c|}{$\mathrm{HF}$} \\
\hline & Mean & SE & Mean & SE \\
\hline \multicolumn{5}{|l|}{ Restrained-eating subjects } \\
\hline Protein balance $(\mathrm{g} / \mathrm{d})$ & 2.1 & 1.7 & -3.3 & 1.6 \\
\hline Carbohydrate balance $(\mathrm{g} / \mathrm{d})$ & $42.0^{*}$ & 6.9 & -6.1 & 3.1 \\
\hline Fat balance $(\mathrm{g} / \mathrm{d})$ & $-20.9 \dagger$ & 2.8 & 11.3 & 5.5 \\
\hline Energy balance $(\mathrm{kJ} / \mathrm{d})$ & $-4 \ddagger$ & 182 & 306 & 214 \\
\hline \multicolumn{5}{|l|}{ Unrestrained-eating subjects } \\
\hline Protein balance $(\mathrm{g} / \mathrm{d})$ & $12.6 \S$ & 3.5 & 2.2 & 3.6 \\
\hline Carbohydrate balance $(\mathrm{g} / \mathrm{d})$ & $56.3 \|$ & 16.5 & 7.8 & 6.2 \\
\hline Fat balance $(\mathrm{g} / \mathrm{d})$ & -32.99 & 7.0 & -3.2 & 3.9 \\
\hline Energy balance $(\mathrm{kJ} / \mathrm{d})$ & -42 & 270 & 70 & 156 \\
\hline \multicolumn{5}{|l|}{${ }^{*} \mathrm{LF} \vee \mathrm{HF}$ diet, $P<.001}$. \\
\hline \multicolumn{5}{|l|}{ tLF $\vee$ HF diet, $P<.001$} \\
\hline \multicolumn{5}{|l|}{ tLF $\vee$ HF diet, $P<.05$} \\
\hline \multicolumn{5}{|l|}{$\S$ LF $\vee$ HF diet, $P<.05}$. \\
\hline \multicolumn{5}{|l|}{$\| \mathrm{LF} v \mathrm{HF}$ diet, $P<.01$} \\
\hline II $F \vee H F$ diet $\rho<.01$ & & & & \\
\hline
\end{tabular}


societies. Furthermore, the overall energy balance can influence whether the body stores excess fuels in the form of body fat or mobilizes energy from body fat. This does not appear to be the case in the present study, where we obscrved a difference of less than $600 \mathrm{~kJ} / \mathrm{d}$ between EI and $\mathrm{EE}$, indicating that subjects were in cncrgy balance during the third day of the study. Energy balance was not significantly different on the three diets (EI-EE $E_{1 . F},-23 \pm 156$ $\mathrm{kJ} / \mathrm{d} ; E I-E E_{\mathrm{M}},+95 \pm 157 \mathrm{~kJ} / \mathrm{d} ; \mathrm{EI}-\mathrm{EE}_{\mathrm{HF}},+188 \pm 131$ $\mathrm{kJ} / \mathrm{d}$ ).

The RQ and NPRQ were significantly higher in restrained-eating subjects on a HF diet, as compared with unrestrained-eating subjects. This suggests a relatively lower oxidation ratio of fat to carbohydrate for restrained eaters, at least on a HF diet (Tables 4 and 5). These findings are in agreement with the results of Hill, ${ }^{28}$ where it was reported that obesity-susceptible individuals have a limited ability to rapidly adjust fat oxidation in response to a $\mathrm{HF}$ intake.
Zurlo et al $^{29}$ associated a low oxidation ratio of fat to carbohydrate with a higher risk of subsequent body weight gain, independent of a low EE.

The results on intake, oxidation, and overall balance of protein, carbohydrate, and fat (Fig 2, Table 6) also showed that substrate oxidation is closer to substrate intake on a HF diet, as indicated by the size of the substrate balances. Alternatively, a LF diet results in a (morc) negative fal balance, reflecting a greater fat oxidation than intake. This suggests that there is (more) net endogenous fat oxidation on a LF than HF diet, implicating a LF diet as a useful tool in the treatment of obesity.

\section{ACKNOWLEDGMENT}

Dr Margriet Westerterp-Plantenga is gratefully acknowledged for her assistance in using the psychometric questionnaires and for valuable comments on the manuscript.

\section{REFERENCES}

1. Flatt JP: The difference in the storage capacities for carbohydrate and for fat, and its implications in the regulation of body weight. Ann NY Acad Sci 499:104-123, 1987

2. Flatt JP: Importance of nutrient balance in body weight regulation. Diabetes Metab Rev 6:571-581, 1988

3. Dreon DM. Frey-Hewitt B, Ellsworth N, et al: Dietary fat:carbohydrate ratio and obesity in middle-aged men. Am J Clin Nutr 47:995-1000, 1988

4. Romieu I. Willett WC. Stampfer MJ, et al: Energy intake and other determinants of relative weight. Am J Clin Nutr 47:406-412, 1988

5. Tremblay A. Plourde G, Despres J-P. et al: Impact of dietary fat content and fat oxidation on energy intake in humans. Am J Clin Nutr 49:799-805, 1989

6. Duncan KH, Bacon JA, Weinsier RL: The effects of high and low energy density diets on satiety, energy intake and eating time of obese and nonobese subjects. Am J Clin Nutr 37:76.3-767, 1983

7. Lissner L, Levitsky DA, Strupp BJ, et al: Dietary fat and the regulation of energy intake in human subjects. Am J Clin Nutr $46 ; 886-892,1987$

8. Hurni M, Burnand B. Pittet $P$, et al: Metabolic effects of a mixed and a high-carbohydrate low-fat diet in man. measured over $24 \mathrm{~h}$ in a respiration chamber. Br J Nutr 47:33-43, 1982

9. Lean MEJ, James WPT: Metabolic effects of isoenergetic nutrient exchange over 24 hours in relation to obesity in women. Int J Obes 12:15-27, 1988

10. Froidevaux F. Scluutz Y, Christin L. El al: Twenly-lour-hour energy expenditure after weight loss in obese subjects. Experientia 44:31a. 1988 (abstr)

11. Thomas CD, Peters JC, Reed GW, et al: Nutrient balance and energy expenditure during ad libitum feeding of high-fat and high-carbohydrate diets in humans. Am J Clin Nutr 55:934-942, 1992

12. Herman CP, Polivy J: Restrained eating, in Stunkard A (ed): Obesity. Philadelphia, PA, Saunders, 1980, pp 208-224

13. Westerterp-Plantenga MS, Van den Heuvel E, Wouters L, et al: Restrained eating, obesity and cumulative food intake curves during four-course meals. Appetite 16:149-158, 1991

14. Stunkard AJ, Messick S: The Three-Factor Eating Questionnaire to measure dietary restraint, disinhibition and hunger. J Psychosom Res 29:71-83, 1985

15. Westerterp-Plantenga MS, Van den Heuvel E, Wouters L. et al: Deceleration in cumulative food intake curves, changes in body temperature, and diet-induced thermogenesis. Physiol Behav $48: 831-836,1990$

16. Westerterp-Plantenga MS, Westerterp KR, Nicolson NA, et al: The shape of the cumulative food intake curve in humans, during basic and manipulated meals. Physiol Behav 47:569-576, 199()

17. Harris JA, Benedict $\mathrm{FG}: \Lambda$ biometric study of hasal metabolism in man. Washington, DC, Carnegie Institute, publication no. 279. 1919. pp 1-266

18. Verboeket-van de Venne WPHG. Westerterp KR: Influence of the feeding frequency on nutrient utilization in man: Consequences for energy metabolism. Eur J Clin Nutr 45:161- I69. 1991

19. Hautvast JGAJ: Ontwikkeling van een systeem om gegevens van voedings enquetes met behulp van een computer te verwerken. Voeding 36:356-361, 1975

20. Flatt JP: Dietary fat, carbohydrate balance, and weight maintenance: Effects of exercise. Am J Clin Nutr 45:296-306, 1987

21. Jéquier E, Acheson K. Schutz Y: Assessment of energy expenditure and fuel utilization in man. Ann Rev Nutr 7:187-208. 1987

22. Siri WE: The gross composition of the body. Adv Biol Med Physiol 4:239-280, 1956

23. Schoffelen PFM, Saris WHM, Westerterp KR. et al: Evaluattion of an automatic indirect calorimeter for measurement of energy balance in man, in Van Es AJH (ed): Human Energy Metabolism: Physical Activity and Energy Expenditure Measurements in Epidemiological Research Based Upon Direct and Indirect Calorimetry. Euro Nutr Rep 5:51-54, 1984

24. Weir JB de V: New methods for calculating metabolic rate with special reference to protein metabolism. J Physiol 109:1-9, 1949

25. Garrow JS: Energy Balance and Obesity in Man. Amsterdam, The Netherlands, North Holland, 1974

26. Abbott WGH. Howard BV, Ruotolo G. et al: Energy expenditure in humans: Effects of dietary fat and carbohydrate. Am J Physiol 258:E347-E351, 1990

27. Hill JO, Peters JC, Reed GW, et al: Nutrient balance in humans: Effects of dict composition. Am J Clin Nutr 54: (1)-17.1491

28. Hill JO: Dietary fat and body weight regulation. Int J Obes 15:MS12, 1991 (suppl 3, abstr)

29. Zurlo F, Lillioja S, Espositio-Del Puente A. et al: Low ratio of fat to carbohydrate oxidation as predictor of weight gain: Study of 24-h RQ. Am J Physiol 259:E650-E657, 1990 